\title{
Polymer materials used in medicine processed by additive techniques
}

\author{
Paweł Turek ${ }^{1), *)}$, Grzegorz Budzik ${ }^{1)}$, Mariusz Oleksy²), Katarzyna Bulanda ${ }^{2)}$ \\ DOI: dx.doi.org/10.14314/polimery.2020.7.2
}

\begin{abstract}
The article presents an overview of currently used polymer materials in various areas of medicine. Most often, polymeric materials are used in the production of medical equipment, cardiology, surgery, dentistry. They are mainly used, among others for the production of gloves, surgical sutures, various type of containers, specula or drip. Currently, by using additive manufacturing techniques, anatomical models of bone structures, surgical templates and implants are made of polymer materials. Thanks to their use, it is possible to significantly reduce the duration of the procedure and increase its precision. By using biodegradable polymers, it is possible to regenerate or replace damaged or diseased tissues or organs. Based on the analysis carried out, huge progress was noted in the use of polymeric materials in the field of medicine through the use of additive methods. However, there is a need for further synthesis of new and modification of existing polymers in the aspect of contact with the patient's body.
\end{abstract}

Keywords: rapid prototyping technologies, polymer materials used in medicine, implants, computed tomography.

\section{Materiały polimerowe stosowane $\mathrm{w}$ medycynie przetwarzane technikami przyrostowymi}

Streszczenie: Artykuł stanowi przegląd materiałów polimerowych wykorzystywanych obecnie w różnych obszarach medycyny. Najczęściej materiały te znajdują zastosowanie w produkcji sprzętu medycznego, w kardiologii, chirurgii, stomatologii, głównie do produkcji rękawiczek, nici chirurgicznych, różnego rodzaju pojemników, wzierników, kroplówek. Obecnie, dzięki zastosowaniu przyrostowych technik wytwarzania, z materiałów polimerowych są wykonywane modele anatomiczne struktur kostnych, szablony chirurgiczne oraz implanty. Ich użycie umożliwia znaczne zredukowanie czasu przeprowadzania zabiegu oraz zwiększenie jego precyzji. Wykorzystanie polimerów biodegradowalnych pozwala na zregenerowanie albo zastąpienie uszkodzonych lub zmienionych chorobowo tkanek i organów. Na podstawie przeprowadzonej analizy stwierdzono ogromny postęp w zakresie stosowania materiałów polimerowych w obszarze medycyny dzięki wykorzystaniu metod przyrostowych. Nadal jednak istnieje potrzeba opracowywania metod syntezy nowych oraz modyfikacji już istniejących polimerów, predestynowanych do aplikacji, w których mają one styczność z organizmem pacjenta.

Słowa kluczowe: technologie szybkiego prototypowania, materiały polimerowe stosowane w medycynie, implanty, tomografia komputerowa.

In the last century, polymeric materials have dominated many industries, including automotive and aviation industry [1, 2]. They occur in natural, modified and synthesis form. The polymers do not have much mechanical and thermal strength, but are generally resistant to

\footnotetext{
1) Rzeszow University of Technology, Department of Mechanical Engineering, al. Powstańców Warszawy 8, 35-959 Rzeszów, Poland.

2) Rzeszow University of Technology, Department of Polymer Composites, al. Powstańców Warszawy 6, 35-959 Rzeszów, Poland.

*) Author for correspondence: pturek@prz.edu.pl
}

atmospheric and chemical factors. They also have good insulating properties and can be easily shaped. Their specific properties and structure, unlike metals and ceramics, allowed them to be distinguished as an independent group of construction materials [3].

In recent years, great progress has been made in the use of polymer materials in contact with the patient's body [4]. Due to the contact of polymer materials with the patient's body, they must meet several requirements. In the first place, they should retain their physicochemical properties despite exposure to high temperature, detergents, X-ray or aseptics. Polymers, like most materials, may degrade after a certain period of time, so it is 
important that their degradation products do not cause for patients, immunological reactions or any other interaction with the body.

The purpose of this article is to provide an overview of currently used polymer materials in various branches of the medical industry. Particular attention was paid to the possibility of their use in the process of making models of anatomical structures, surgical templates in bone surgery and dentistry with the using additive methods.

\section{THE USE OF POLYMERIC MATERIALS IN THE 3D PRINTING PROCESS}

Polymer materials are most often used for the production of medical equipment. The most commonly used polymeric materials for this purpose are: polyethylene (PE), polypropylene (PP), polystyrene (PS), polyesters, poly(vinyl chloride) (PVC) or polycarbonates (PC).These materials are used, among others things, for the production of gloves, surgical sutures, various type of containers, specula or drips. Polymer materials used in the production of devices are relatively cheap, which allows them to be used in the production of disposable products.

Currently, the development of polymeric materials is focused in the preparation and use of reinforced plastics, for example nanocomposites and hybrid nanocomposites [5]. Modification of polymers, including polymer composites with nanofillers, is currently one of the fastest growing fields. The main reason for using hybrid reinforcements is the possibility of obtaining hybrid nanocomposites with better performance pro- perties (such as mechanical strength, stiffness, impact strength), which is very important when used in field of medicine. A well-developed hybrid nanocomposite uses the benefits of individual components to minimize the disadvantages of using these components individually. Additive methods in which hybrid polymeric materials are used include technology: SLA (stereolithography), SLS (Selective Laser Sintering), FDM (Fused Deposition Modeling) or PolyJet [6, 7]. Particularly in recent times, there has been a significant increase in the use of rapid prototyping methods in the production of anatomical structure models [8] (Fig. 1), surgical templates and implants in bone surgery and dentistry. Hybrid polymer materials have also been used in the process of making prostheses, orthoses and selected elements of the exoskeleton for people with limb paralysis.

Various biocompatible polymer materials are used for printing, among others thermoplastic, photopolymers in liquid and powder form (Table 1). Additive methods have also been used for many years for production of scaffolds from different groups of biocompatible polymers materials $[9,10]$. Description of this group of applications has been presented in many publications [11], which is why it is omitted in this work.

\section{Models of anatomical structures for applications in craniofacial area}

Polymer materials used in bone surgery must have good mechanical properties and high strength in biological systems. They are used for the production of ten-
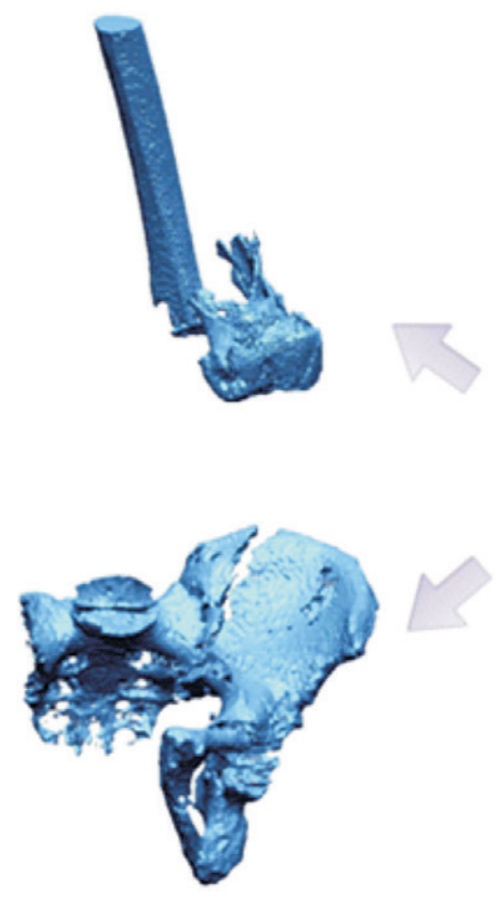

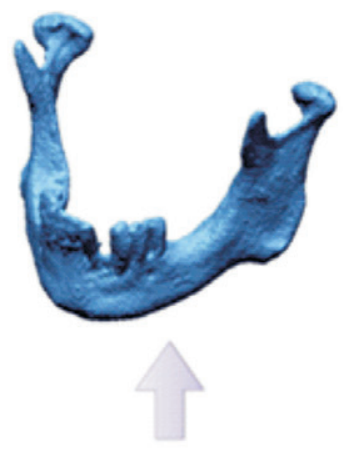

ANATOMICAL MODELS

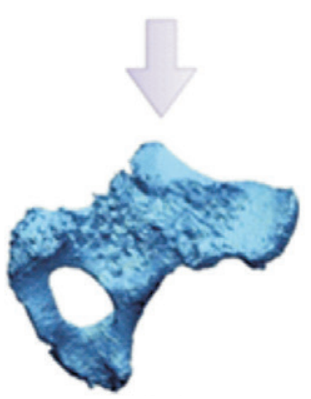

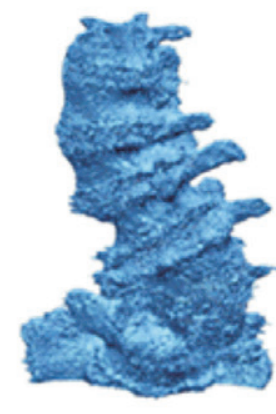
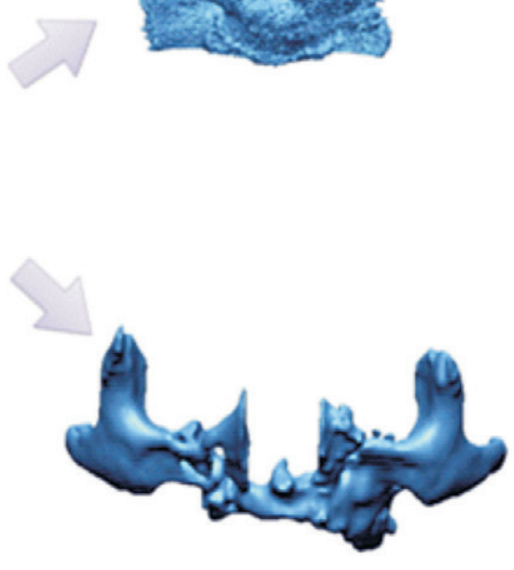

Fig.1. Anatomical models of bone structures 
$\mathrm{T}$ a b 1 e 1 . Biocompatible polymer materials used in the $3 \mathrm{D}$ printing process

\begin{tabular}{|c|c|c|}
\hline 3D printing technique & Name and selected types of materials & Area of application \\
\hline \multirow{5}{*}{$\begin{array}{l}\text { Fused Deposition } \\
\text { Modeling (FDM) }\end{array}$} & $\begin{array}{l}\text { Acrylonitrile-butadiene-styrene (ABS) } \\
\text { e.g. ABS-M30i }\end{array}$ & Products in contact with skin, food and medicines \\
\hline & $\begin{array}{l}\text { Polycarbonate (PC) } \\
\text { e.g. PC-ISO }\end{array}$ & $\begin{array}{c}\text { Pharmaceutical industry, biomedical } \\
\text { engineering, food packaging }\end{array}$ \\
\hline & Polylactide (PLA) & $\begin{array}{l}\text { Used to receive surgical sutures } \\
\text { and dental implants }\end{array}$ \\
\hline & $\begin{array}{l}\text { Polyetherimide (PEI) } \\
\text { e.g. ULTEM } 1010\end{array}$ & Production of surgical and dental instruments \\
\hline & $\begin{array}{l}\text { Polyetheretherketone (PEEK) } \\
\text { e.g. LUVOCOM 3F PEEK } 9581\end{array}$ & Production of surgical and dental instruments \\
\hline Material Jetting (PolyJet) & $\begin{array}{c}\text { Acrylic resins } \\
\text { e.g.: MED610, VeroGlaze (MED620), } \\
\text { VeroDent MED670, } \\
\text { VeroDentPlus MED690 }\end{array}$ & $\begin{array}{l}\text { Dentistry, orthodontic laboratories } \\
\text { in the production of, among others } \\
\text { crowns and dental bridges }\end{array}$ \\
\hline $\begin{array}{l}\text { Selective Laser } \\
\text { Sintering (SLS) }\end{array}$ & $\begin{array}{l}\text { Polyamide (PA) } \\
\text { PA } 2105\end{array}$ & Production of dental instruments \\
\hline Stereolithography (SLA) & $\begin{array}{c}\text { Acrylic resins } \\
\text { e.g.: denture base and teeth } \\
\text { dental model resin, dental SG } \\
\text { resin, dental LT clear } \\
\text { epoxy resin } \\
\text { e.g. Accura }{ }^{\circledR} \text { ClearVue }{ }^{\mathrm{TM}}\end{array}$ & $\begin{array}{l}\text { Production of precise surgical } \\
\text { measures and dental models }\end{array}$ \\
\hline $\begin{array}{c}\text { Digital Light } \\
\text { Processing (DLP) }\end{array}$ & $\begin{array}{c}\text { Acrylic resins } \\
\text { e.g.: 3Delta Model 320, 3Delta Model Ortho }\end{array}$ & $\begin{array}{l}\text { Production of prosthetic models, gingival } \\
\text { masks, surgical templates, orthodontic models }\end{array}$ \\
\hline
\end{tabular}

don prostheses (polyester fabric), hip joints [poly(methyl methacrylate)], hand joints (silicone rubber) or bones (polyester plates). Currently, polymeric materials are used in the 3D printing process in the process of making mainly models of anatomical structures.
The use of anatomical structure models in the processes of facial cranial reconstruction is becoming more and more popular, and in some cases even necessary. Often, as a result of bone cancer being detected within the patient's mandible, a resection process is performed. To
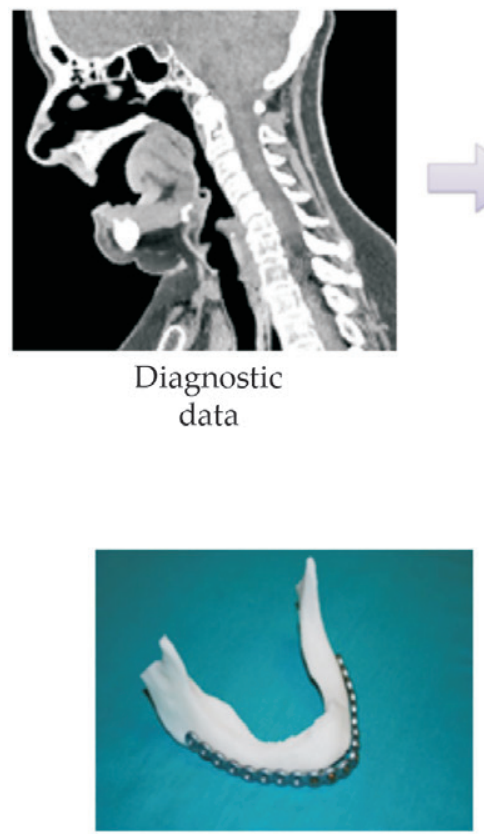

Printed mandible model with pre-bended surgical plate

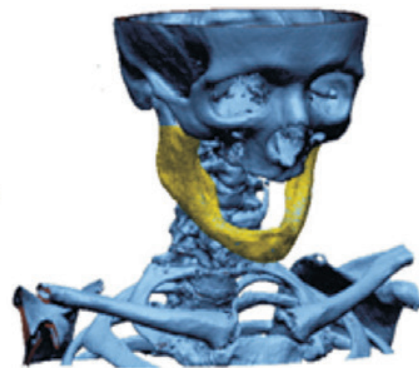

Three dimensional representation

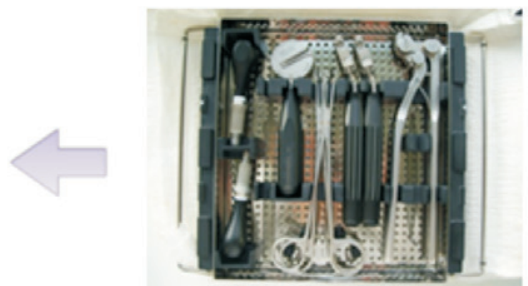

Surgical instruments

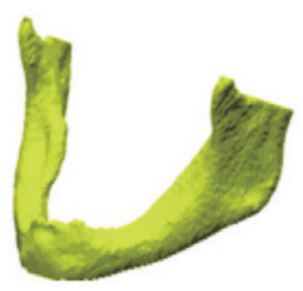

Segmented mandible geometry

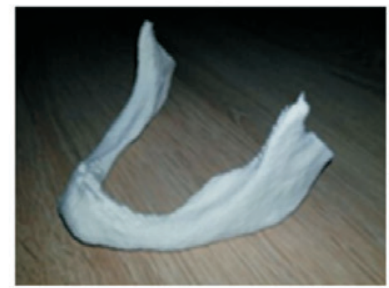

Printed

3D model

Fig. 2. Application of the printed anatomical model in the mandible 
a)

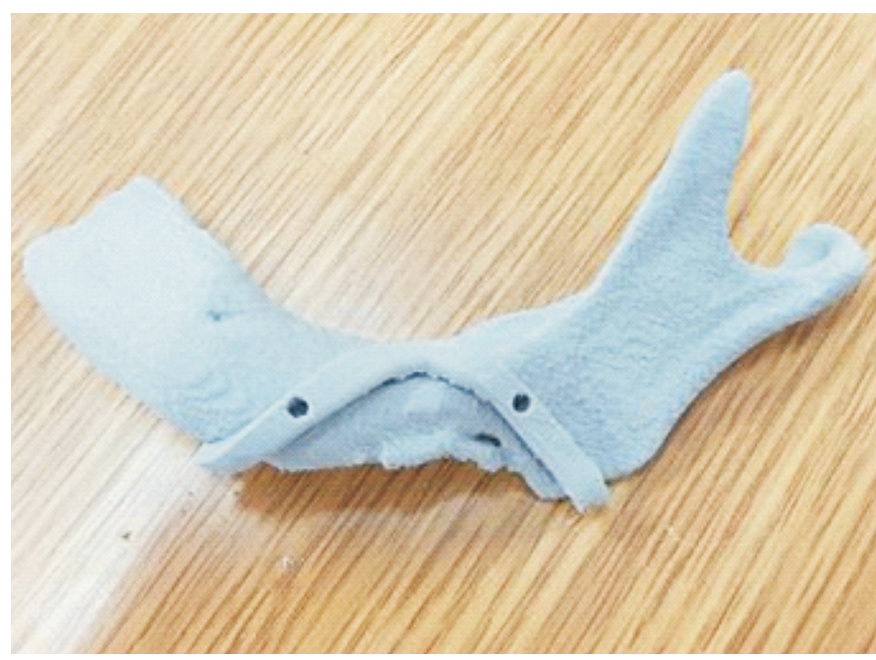

b)

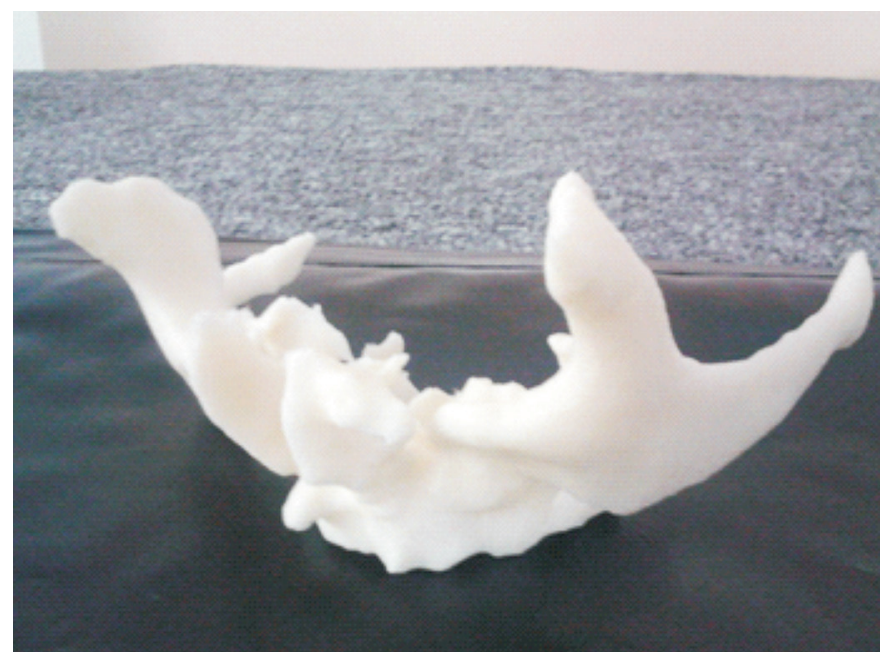

Fig. 3. Printed from thermoplastic polymer material: a) model of the mandible with a surgical template, b) area of the upper jaw

restore the mandible continuity after such a procedure, autogenous transplants or surgical plaques are traditionally used. In order to improve the course of the surgical process, the digital model of the mandible is reconstructed and its physical equipment is performed by using the additive method (Fig. 2).

A model of the mandible anatomical structure was made at the Rzeszow University of Technology in the Department of Mechanical Engineering. The printed model was used in the planning of the procedure, which was carried out at the Maxillo-Facial Surgery Clinic in Rzeszow. The main benefits that have been observed after the surgery are due to the possibility of preoperative process planning and direct bending of the surgical plate prior to surgery. The effect of using the model is to reduce the time of surgery (general anesthesia), reduce the patient's blood loss during the procedure and minimize intraoperative complications. In addition, not only prints of anatomical structure models are currently made, but also surgical templates adapted to their geometry (Fig. 3a). They allow you to precisely guide to surgical tool during the procedure.

In the event of atrophy of the alveolar ridge of the upper jaw bone, methods are used to restore chewing function and improve the patient's aesthetics. They consist mainly of bone tissue transplantation from another place of the patient's body. Currently, for this purpose, anatomical structure models made with incremental techniques are used (Fig. 3b).

The models presented in Fig. 3 were made at the Rzeszow University of Technology in the Department of Mechanical Engineering (Fig. 3a) and Department of Manufacturing Techniques and Automation (Fig. 3b). Printed models were used in the planning of procedures carried out at the Maxillo-Facial Surgery Clinic in Rzeszow.

The model (Fig. 3b) allowed to determine the place and estimate the volume needed to collect the autogenous transplant. As a result of using the model, the procedure was accelerated, the amount of transplant collected was reduced, and the bone defect was more aesthetically filled.

\section{Anatomical models and implants for hip and knee applications}

Joint injuries occur extremely often, both during sports, at work and during everyday activities. Hip and knee replacement is currently one of the most common orthopedic surgeries. Unfortunately, like any invasive procedure, arthroplasty procedures are at risk of complications that can reduce the good outcome of the surgery and instead of improving - lowering the patient's quality of life. Therefore, also in this area currently used models of anatomical structures and ready implants made with additive techniques (Fig. 4).

A femoral anatomical structure model was made at the Rzeszow University of Technology in the Department of Mechanical Engineering. The printed model was used in the planning of the procedure, which was carried out at the Department of Traumatology and Orthopaedics of Adult Movement Organs in Rzeszow.

As a results of using the model, the procedure was accelerated. One year after the prosthesis was put in place and the individual rehabilitation program applied, a painless range of knee joint movement in range of $0-100^{\circ}$ was obtained enabling independent movement. Control postoperative radiographs showed no signs of implant loosening.

\section{Implants and models used during dental procedures}

Polymer materials have found application in such fields of dentistry as prosthetics, orthodontics, prophylaxis, conservative dentistry and surgery. In prosthetics and orthodontics, using 3D printing methods are made: dentures, artificial teeth, individual spoons and orthodontic appliances. 


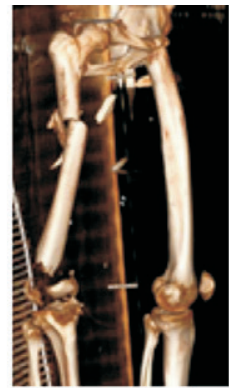

Diagnostic data (after the accident)

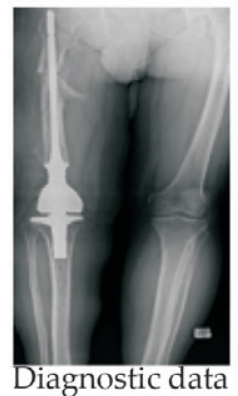

(second surgical reconstruction)

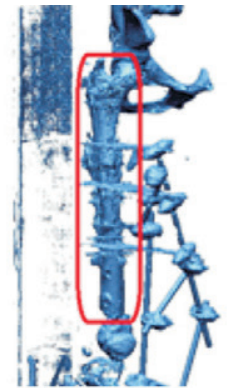

Three dimensional representation (first surgical reconstruction)

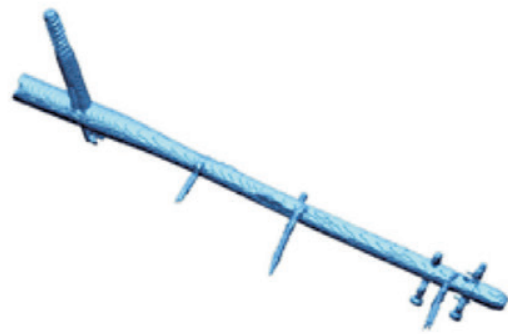

Segmented traction pin
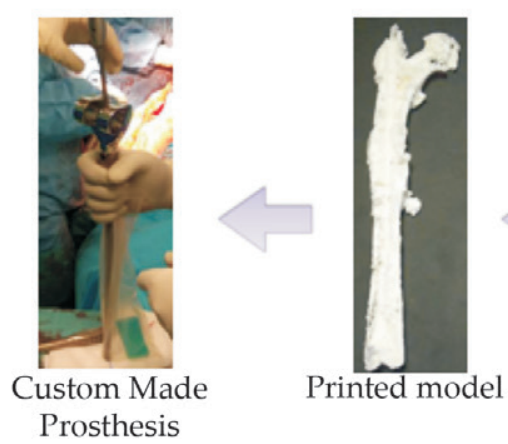

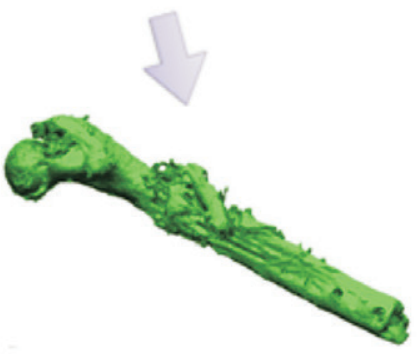

Three dimensional model

Fig. 4. Application of the printed anatomical model within the femur

a)

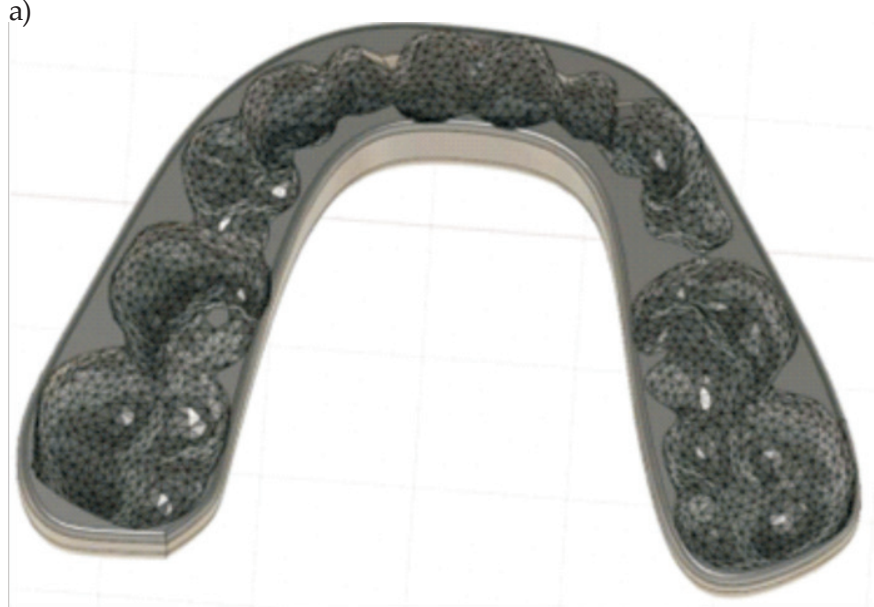

b)

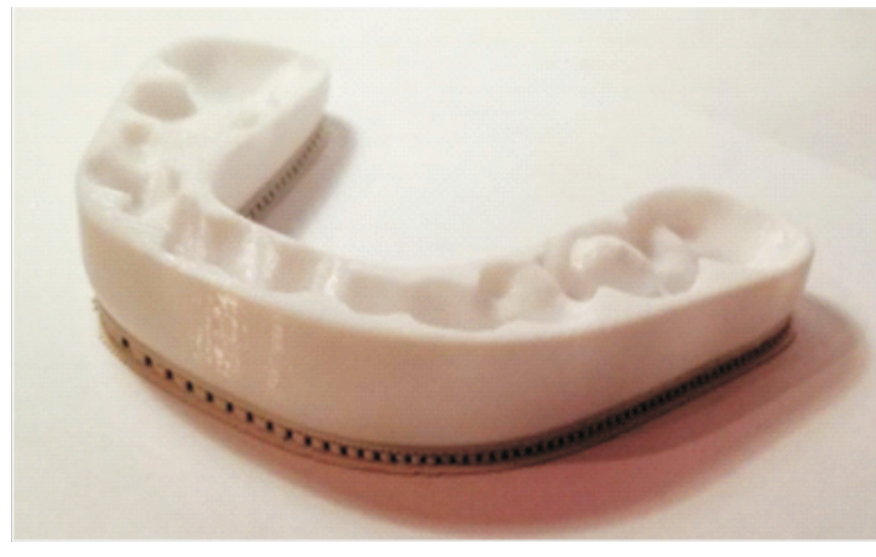

Fig. 5. Relaxation splint: a) three-dimensional design, b) printed prototype of the model

For years, dental prostheses have been produced in the world by a labor-intensive method: first, the so-called impression and plaster model, then wax, which is then replaced by acrylic plastic which is already the right denture. The final stage of the entire process is also the most time consuming and error prone. Currently in dental diagnostics, models are printed to directly illustrate that patient's teeth without intermediate stages. Models printed directly by additive methods are characterized by high accuracy, which allows for very precise measurements that are necessary for prosthetic or orthodontic treatment. To create a denture, PolyJet or DLP technology (material: acrylic resins) is most often used.

Modern orthodontics also uses special orthodontic overlays that are designed to correct minor occlusal defects. An exemplary project and prototype of splint model printed at the Department of Manufacturing Techniques and Automation for a private orthodontic clinic in Rzeszow are presented in Figs. 5a and 5b. Most often, splint models are printed using PolyJet or DLP methods. Printed splint models are adapted to the individual conditions in the patient's mouth. However, in the last phase of orthodon- 
tic treatment, in order to stabilize the effect obtained, additional retention overlays are used. They can be made using PolyJet, DLP and SLA methods.

Currently, printed splint are also made of biocompatible materials used during surgical procedures. Their goal is to enable, among others piloting of the drill during surgery and subsequent secure implant placement. The use of templates in dentistry is very convenient for the surgeon, as it significantly reduces the time of the procedure.

\section{SUMMARY}

Currently, polymeric materials are widely used in many areas of medicine. Most often, polymeric materials are used in the production of medical equipment, surgery and dentistry. By using 3D printing methods, it is possible to make anatomical models of bone structures, surgical templates and implants. Particularly they find their place in the process of reconstruction of the areas of the craniofacial, hip or knee joint and dentistry. They allow, among others on: better preparation for the procedure, increasing the precision of the performed operation, choosing the necessary equipment during the procedure, reduction of surgery time (general anesthesia), reduction of blood loss during surgery, minimizing intraoperative complications.

The presented conclusion prove that models made with additive techniques are additional support for doctors during performing complex surgical procedures. However, there is a need for further synthesis of new and modification of existing polymers in the aspect of contact with patient's tissues, in order to improve their mechanical, strength and biocompatibility properties.

\section{REFERENCES}

[1] Dziubek T., Oleksy M.: Polimery 2017, 62, 44. http://dx.doi.org/10.14314/polimery.2017.044

[2] Dziubek T.: Polimery 2018, 63, 49. http://dx.doi.org/10.14314/polimery.2018.1.8

[3] Oleksy M., Budzik G., Sanocka- Zajdel A. et al.: Polimery 2018, 63, 531. http://dx.doi.org/10.14314/polimery.2018.7.7

[4] Asadi N., Del Bakhshayesh A.R., Davaranet S. et al.: Materials Chemistry and Physics 2019, 122528. https://doi.org/10.1016/j.matchemphys.2019.122528

[5] Yener A.: Journal of Polymer Engineering 2019, 39, 178. https://doi.org/10.1515/polyeng-2017-0452

[6] Budzik G., Turek P., Dziubek T., Gdula M.: Measurement and Control 2020, 53, 181. https://doi.org/10.1177/0020294019881708

[7] Turek P.: Polimery 2019, 64, 522. http://dx.doi.org/10.14314/polimery.2019.7.9

[8] Ciocca L., Mazzoni S., Fantini M. et al:: Medical \& Biological Engineering \& Computing 2012, 50, 743. http://dx.doi.org/10.1007/s11517-012-0898-4

[9] Park J., Jung J.W., Kang H-W, Cho D-W: Biofabrication 2014, 6, 025003. http://dx.doi.org/10.1088/1758-5082/6/2/025003

[10] Lobo D.A., Ginestra P.: Materials 2019, 12, 4005. http://dx.doi.org/10.3390/ma12234005

[11] Asghari F., Samiei M., Adibkia K. et al.: Artificial Cells, Nanomedicine, and Biotechnology 2017, 45, 185. https://doi.org/10.3109/21691401.2016.1146731

Received 6 III 2020 